\title{
CURRENT TRENDS IN THE DEVELOPMENT OF ECOLOGICAL CULTURE IN RUSSIA
}

\author{
(C) Yulia V. Maslova \\ Platov South-Russian State Polytechnic University (NPI), Novocherkassk, \\ Russian Federation \\ yuliamaslova@gmail.com
}

The peculiarities of Russian ecological culture in the perestroika and post-perestroika periods are considered, as well as its development at the beginning of the $21^{\text {st }}$ century. Modern Russian society is characterized by the desire for "institutional forgetting" and washing out traditional forms of ecological culture, forming an individualistic ("fragmented") ecological consciousness that can be manipulated by interested communities united by financial interests. The consequence is a massive speculative use of environmental culture factors to achieve political goals. The polarization of the environment and the transformation of the general Russian natural landscape into zones of the greatest ecological comfort and zones of ecological abandonment is the result of the sharp polarization of society on the grounds of property status. Under these conditions, the situation of several ecological zones` formation in the territory of one country arises. The need to eliminate the centres of ecological disaster left as an inheritance of the USSR becomes an independent environmental factor, on the basis of which it is possible to create really interested in ensuring the environmental comfort organizations and the institutional environment. Modern Russian society at the level of public consciousness is fully aware of the need to create a practically oriented environmental education, which is based on humanistic values, which is an essential condition for the sustainable development of modern society.

Key words: ecological culture, perestroika and post-perestroika periods, modern Russian society, natural resources, ecological consciousness.

\section{[Ю.В. Маслова Современные тенденции развития экологической культуры в России]}

Рассматриваются особенности отечественной экологической культуры в перестроечный и постперестроечный периоды, а также ее развитие в начале XXI в. Современное российское общество характеризуется стремлением к «институциональному забыванию» и вымыванию традиционных фрорм экологической культуры, формируя индивидуалистическое («раздробленное») экологическое сознание, поддающееся манипулированию со стороны заинтересованных сплоченных финансовыми интересами сообществ. Следствием этого является массированное спекуляционное использование фракторов экологической культуры для достижения политических целей. Поляризация окружающей среды и превращение общего российского природного ландшафта в зоны наибольшего экологического комфорта и зоны экологической заброшенности оказывается следствием резкой поляризации общества по имущественному признаку. В указанных условиях возникает ситуация образования на территории одной страны нескольких экологических зон. Необходимость элиминации очагов экологического бедствия, оставшихся в качестве наследства СССР, становится независимым экологическим фактором, на основе которого возможно создание действительно заинтересованных в обеспечении экологического комфорта организаций и институциональной среды. Современным российским обществом на уровне общественного сознания в полной мере осознается необходимость создания практически ориентированного экологического образования, в основе которого лежат гуманистические ценности, что является существенным условием устойчивого развития современного социума.

Ключевые слова: экологическая культура, перестроечный и постперестроечный периоды, современное российское общество, природные ресурсы, экологическое сознание.

Yulia V. Maslova - Associate Professor, Platov South-Russian State Polytechnic University (NPI), Novocherkassk, Russian Federation.

Маслова Юлия Владимировна - доцент, Южно-Российский государственный политехнический университет (НПИ) имени М.И. Платова, е. Новочеркасск, Российская Федерация. 


\section{Introduction}

The modern period of ecological culture development in Russia should be started from the 80 s of the last century. This choice was due to the need to focus on that historic turning point, during which a new geopolitical space arose in the territory of the USSR, torn apart by contradictions between political elites. The social, political and economic sphere during the perestroika and post-perestroika periods of modern Russia was accompanied by ruptures of relations, economic relations and geopolitical transformations.

But perestroika gave rise not only to the modern geopolitical structure of Russia. Rather quickly, the established values of a socialist communal society were replaced by the new values of capitalism of the early stage of accumulation. The division of former state property, the collapse of hopes for a stable future not only for families, but also for entire cities, has determined the secondary place of ecological culture throughout the whole value space. Sharp value shifts during social transformations in Russian society have dramatically changed human attitudes towards the environment.

\section{Domestic ecological culture in the perestroika and post-perestroika periods}

The perestroika and post-perestroika periods can be divided into two sharply different time intervals: 1) 1985-1990 - the time of ecological inertia, during which everyday and romantic concern about the environmental situation of the region, as well as the care of urban space cleanliness, was still preserved; 2) 1993-1999 - the period of protracted crisis during which environmental problems actually ceased to occupy the minds of political leaders, and the population was concerned not so much with ecology as with the survival of their families. Nevertheless, these periods are elements of the general canvas of the events of the socio-political and economic transformation of Russian (Soviet) society and its subsequent social trauma. It was in these conditions that current trends in the development of environmental culture in Russian society were formed.

In the period from 1985 to 1990 Soviet society adopted the installation on the ecologization of production, life and leisure as general imperatives. At the same time, general ecologization was often in one way or another associated with the political institutions of democracy and liberalism, which were observed outside the USSR. The gradual increase of ecological consciousness naturally moved to the new qualitative level: the institutionalization of environmental consciousness and social activity began. A network of environmental periodicals was developed, environmental services and an expert community were created [2].

Putting the environmental issue as one of the items on the general socio-political agenda in the periodical press ensured a fairly rapid growth in environmental consciousness, the understanding of the possible destabilization of the environment came, the Soviet person thought about the future of his children in the conditions of a colossal industrial burden on the country's biosphere.

But the environmental movement, gaining this direction towards environmental education through the periodic press, had the opposite side. Environmental problems and their publicity have become a convenient base for the political career of environmental party leaders [6]. Their gradual entry into the new political beau monde of the country, as it turned out, contributed not so much to solving problems as to the politicization and bureaucratization of the decision processes, and subsequently the conditions for environmental speculation were created, the purpose of which was the struggle for budget funds. Thus, the growing environmental movement was turned into a socio-political simulacrum, which, in the context of the struggle for power in a transforming society, was used exclusively for political games.

The restructuring of the socio-political space of the late 80s-early 90 s of the 20th century led to the spontaneous repetition of the situation of the 20-40s, during which mass migrations, the rupture of cultural roots and the loss of traditional national domestic ecological culture were 
carried out. The consequences of privatization and property redistribution have led to disastrous social tensions. Refugees, beggars, a huge number of highly qualified unemployed people created a negative "energy of social breakdown," which repeatedly increased in the situation of the country's economic life breakdown, in particular, the rupture of cooperative relations between Russian industrial enterprises and organizations serving their needs and located in the territories of newly formed countries in the post-Soviet space.

The environmental consequence of such a socio-political explosion was the phenomenon of a huge number of centers of abandonment and their transformation into zones of ecological disaster.

For several years, the phenomenon of sharp polarization of ecological zones has appeared. Territories accessible to the majority during the USSR found their owners; zones of the greatest environmental favor appeared in them. At the same time, ecological disaster zones appear, polluted, abandoned, zones that accumulate human waste and industrial production waste.

It is noteworthy that the suddenly appearing nouveau riche formed a kind of new Russian ecological paradigm, reminiscent of the maxim of Louis XV "After us, the flood." While maintaining the value of liberalism and democratization and associating it with the high level of ecologization of Western countries, the "new Russians" arranged their own life, accompanied by a high level of environmental comfort abroad, while trying to save on waste treatment plants and environmental fees in their enterprises in Russia. The accelerated achievement of Russia's stability was actually made possible by the creation of several monopoly corporations controlling non-renewable resources.

When the ecological well-being of regions became directly dependent on the interest of the decision-making person or the financial corporation interested in the production of natural resources in their territory, depressed regions, excluded from the list of modernized ones, were immediately formed. Under these conditions, the situation of the formation of several ecological zones in the territory of one country arises: 1) a zone of the greatest ecological comfort; 2) a zone of mediocre ecological comfort, ranked according to the established list of factors; 3 ) an ecological disaster zone in which a culture of poverty grows, incompatible with the high requirements of ecological culture and value attitude to the environment. In such zones, there is a return to the obsolete forms of everyday life and farming, which sometimes leads to overexploitation of resources and emergence of the phenomenon of environmental crime.

In addition to these negative trends in modern globalizing Russian society, the factor of accelerating consumerism, which appeared during the researched period in the form of "commodity hunger" against the background of a constant deficit, is increasing. The apparent incompatibility between advertising lifestyles and actual living conditions in regions with high environmental risk increases social tensions and, in turn, increases the burden on the local biosystem, which is being ruined in pursuit of the illusion of domestic benefits in ecological disaster zones. The utilitarian attitude towards the natural resources of the place of life is one of the negative valuable trends formed during the transition period.

Nevertheless, during the transition period, ideologemes were proposed in the ideological propaganda space, allowing the population to hope for better living conditions, accompanied by an increase in the quality of the environmental situation. In this case, the obsolete imperative in Western countries about the "invisible hand of the market" was used [3]. The thesis of the correctness of all current changes was imposed on the population; in accordance with the socialist model of the "better tomorrow," calling to sacrifice the present, the population was asked to "wait" not so much for a totally controlled as for a spontaneously self-governing order. This thesis was contradicted by attempts to create a managed civil society, to maintain the vertical of power, including in the economic sphere of Russian society, through the management of new resource monopolies. 
The described distorting of public administration in the context of a crisis transformation inevitably affected the quality of the environmental situation in the country, as well as the ecological culture of a new generation. The country was in the situation of social order changing, the need to maintain its defence capacity, the demographic crisis and the need to maintain the proper level of innovation that would preserve staff capacity (human capital). The need for the catch-up modernization in the context of socio-political and economic crisis had distorted the very idea of modernization, in which the key element was a careful attitude to natural resources.

In transformable Russia of the 90s, modernization was of the opposite nature and it was carried out on the principle of "at all costs." The exploitation of resources and the human price for the reforms was one of the reasons for the new market relation to nature, which can be expressed by the following wording: "nature is the source of resources for modernization and the storage of its waste, its ecosystem properties have a market value" [8, p.153].

The environmental trends of the 90 s could be formulated as a violation of the Soviet ideology and culture, with the help of demands imposed from above that were contrary to the attitudes of socialist society. The unequivocal putting the entire Soviet with the "minus" sign and the entire Western with the "plus" sign on the scale of values led the country to the colossal decline, accompanied by the growing plundering of natural wealth.

\section{$21^{\text {st }}$ century}

Transformations of ecological culture in Russian society of the beginning of the

In the early 2000s, Russia gradually regained the status of a geopolitical player in the political arena. As a result, the country begins to participate in international treaties regulating the environmental burden in industrial production, as a result of which the role of legal factors in the development of environmental culture is increased [4]. Since this moment the latest stage of ecological culture formation in Russia has started. It is characterized by two divergent trends: the need for openness to the world, on the one hand, conflicts with its own internal and external socio-economic and political interests.

The leading interests of Russia are the strengthening of the country's defence capacity, the restoration of lost economic ties with the former republics of the USSR, the construction of energy pathways, and the construction of a new economy forcedly. All these tasks require a change in the content of the population's consciousness, as well as the formation of a new ecological culture.

Among the international challenges arising from the proposed principles and changing the course of Russia's environmental policy there are quite controversial, but constantly appearing at the level of international environmental policy, questions about the greenhouse effect and environmental terrorism, the need to preserve natural and cultural monuments and the combining for this purpose efforts of the international community.

At the level of direct consumption, the problem of cleanliness of the most demanded natural resources is becoming more acute. If earlier the list of environmental problems was limited to known geological and biological phenomena: soil erosion and weathering of the fertile layer, water pollution, destruction of biogeocenosis of forest and swampy areas, today it is possible to record the appearance of peculiar environmental risks: genetically modified products, the risks of an epidemic from burials (viruses in burial grounds persist for more than 100 years), the expansion of drug addiction epidemic, etc.

Due to the sharp polarization of income in Russia, social stratification is also increasing. Nowadays the division of society into a wide segment of the population with incomes below the poverty line and a small layer of the super-rich economic elite, extreme poverty and excessive wealth have become a significant negative tendency in the modern socio-economic situation [1]. The growing irritation due to the obvious injustice of the distribution of income of Russian society leads, among other things, to clear violations of environmental safety standards. Such violations become especially evident when observing the waste management in disadvantaged areas. 
Reducing social stress by establishing an effective waste management system is both an environmental and policy act. Thus, the categories "ecological culture," "modern society," "social tension" turn out to be intersecting concepts that require an integrated approach in solving problems of environmental and political comfort.

Nevertheless, today the prospect of environmental organizations in the political arena is still unclear. As O.N. Yanitsky emphasizes, "by the end of the 90s a type of ecological culture that meets the interests of TNC had been formed. Its central point is eco-management. Its essence and focus are the protection of systems of extraction and exploitation of natural resources both from the local population and from the pressure of public opinion, that is, the neutralization of resistance to the environmental community. In fact, this is a new stage in the development of a utilitarian culture that reflects the interests of private and public structures for the extraction and processing of natural resources (oil, gas, timber) and their consumers" [8, p. 156].

As part of the eco-management, which seeks maximum control over environmental legislation and public opinion, it is proposed to replace the opinion of residents ("ecological culture of the place") with expert judgement. If the opinion of the population is difficult to manipulate, then the administrative nature of the expert community is quite amenable to both economic and political-administrative manipulation. The main goal of building such a strange entity as an environmental expert community within the framework of eco-management is to rationalize the use of natural resources.

The wide meaningful context of the word "rationalization" allows to use it in different contexts. If an ordinary resident of the region can conceive of rationalization as a desire to preserve wealth of nature as efficiently as possible, then from a TNC perspective rationalization is understood as the most efficient investment in natural resource development for profit. At the same time, the chances of the regional environmental community against the interests of TNC tend to zero, since "local worlds (territorial communities) cannot resist powerful and mobile global structures. This is not possible even for individual States" [8, p.157]. And indeed, as Z. Bauman emphasizes, modern capital "has become extraterritorial to an unprecedented degree... and unattached to one place, and the level of spatial mobility achieved by it is sufficient to blackmail localized political institutions in order to force them to abandon their claims" [1, $p$. 32].

\section{Conclusion}

These processes of transformational Russian society reveal a number of general trends in the development of ecological culture at the present stage of Russian history.

Modern Russian society is characterized by the desire for "institutional forgetting" and washing out traditional forms of ecological culture, forming an individualistic ("fragmented") ecological consciousness that can be manipulated by interested communities united by financial interests. The consequence is a massive speculative use of environmental culture factors to achieve political goals. In this case, the environmental situation loses its value and becomes only a temporary tool for achieving third-party goals.

The polarization of the environment and the transformation of the general Russian natural landscape into zones of the greatest ecological comfort and zones of ecological abandonment is the result of the sharp polarization of society on the grounds of property status. Under these conditions, the situation of several ecological zones' formation in the territory of one country arises: 1) a zone of the greatest ecological comfort; 2) a zone of mediocre ecological comfort, ranked according to the established list of factors; 3) an ecological disaster zone.

The need to eliminate the centres of ecological disaster left as an inheritance of the USSR becomes an independent environmental factor, on the basis of which it is possible to create really interested in ensuring the environmental comfort organizations and the institutional environment. Modern Russian society at the level of public consciousness is fully aware of the need to create a practically oriented environmental education [5], which is based on humanistic 
values [9; 10], which is an essential condition for the sustainable development of modern society [7].

\section{Лumepamypa}

1. Бауман 3. Индивидуализированное общество. М.: Логос, 2005.

2. Белов И.Ю., Фомичев С.Р. Зеленая библиография. Периодические экологические издания Северной Евразии. М.: Центр охраны дикой природы, 1999.

3. Коган А.М. Макрорегулирование высокоразвитого рынка: «Невидимая рука», конкуренция, потребности системы // Современная конкуренция. 2007. № 4. С. 98-103.

4. Маслова Ю.В. Экологическая культура в современной России: социально-правовые фракторы развития // Гуманитарные и социально-экономические науки. 2020. № 5 (114). C. 9-14.

5. Маслова Ю.В. Экологическое образование как фактор развития экологической культуры в современном российском обществе // Гуманитарные и социальные науки. 2020. № 5. С. 270-278.

6. Фомичев С.Р. Разноцветные зеленые: стратегия и действие. М.: Центр охраны дикой природы. 1997.

7. Шевченко О.М., Штоорер Л.Л. Экологическое сознание и экологическая культура в решении проблем устойчивого развития современного социума // Гуманитарий Юга России. 2020. № 3. С. 232 - 247.

8. Яницкий О.Н. Экологическая культура России XX века: очерк социокультурной динамики // История и современность. 2005. №1.

9. Kovaleva T.N., Maslova Yu.V. et al. Ecohumanistic Education in Russia and China as a factor of sustainable development of modern civilization // Dilemas Contemporaneos: Educacion, Politica y Valores. 2019. Vol. 6. Access mode: https://dilemascontemporaneoseducacionpolitica-yvalores.com

10. Olenich T.S., Maslova Yu.V., Klimenko T.M., Zakharova V.A., Astakhova A.I., Vodenko K.V. Eco-Legal Education and Religious Values: The Opportunities of Convergence // Ekoloji. 2019. Vol. 28. № 107. Pp. 5045-5048.

\section{References}

1. Bauman Z. Individualizirovannoe obshchestvo [Individualized society]. Moscow: Logos. 2005 (in Russian).

2. Belov I.Yu., Fomichev S.R. Zelenaia bibliografiia. Periodicheskie ekologicheskie izdaniia Severnoi Evrazii [Green bibliography. Periodicals of environmental publications of Northern Eurasia]. M.: Tsentr okhrany dikoi prirody. 1999 (in Russian).

3. Kogan A.M. Makroregulirovanie vysokorazvitogo rynka: "Nevidimaia ruka", konkurentsiia, potrebnosti sistemy. Sovremennaia konkurentsiia [Macro-regulation of a highly developed market: "Invisible hand," competition, needs of the system. Modern competition]. 2007. No. 4. pp. 98-103 (in Russian).

4. Maslova Yu.V. Ekologicheskaia kultura v sovremennoi Rossii: sotsialno-pravovye faktory razvitiia [Ecological culture in modern Russia: socio-legal factors of development]. Gumanitarnye i sotsialno-ekonomicheskie nauki. 2020. No. 5 (114). pp. 9-14 (in Russian).

5. Maslova Yu.V. Ekologicheskoe obrazovanie kak faktor razvitiia ekologicheskoi kultury v sovremennom rossiiskom obshchestve [Environmental education as a factor in the development of ecological culture in modern Russian society]. Gumanitarnye i sotsialnye nauki. 2020. No. 5. pp. 270-278 (in Russiann).

6. Fomichev S.R. Raznotsvetnye zelenye: strategiia i deistvie [Multi-coloured green: strategy and action]. M.: Tsentr okhrany dikoi prirody. 1997 (in Russian). 
7. Shevchenko O.M., Shtofer L.L. Ekologicheskoe soznanie i ekologicheskaia kultura v reshenii problem ustoichivogo razvitiia sovremennogo sotsiuma [Ecological consciousness and ecological culture in solving the problems of sustainable development of modern society] Gumanitarii luga Rossii. 2020. No. 3. pp. 232 - 247 (in Russian).

8. Yanitsky O.N. Ekologicheskaia kultura Rossii XX veka: ocherk sotsiokulturnoi dinamiki. Istoriia i sovremennost [Ecological culture of Russia of the 20th century: an essay on socio-cultural dynamics. History and modernity]. 2005. No. 1 (in Russian).

9. Kovaleva T.N., Maslova Yu.V. et al. Ecohumanistic Education in Russia and China as a factor of sustainable development of modern civilization. Dilemas Contemporaneos: Educacion, Politica y Valores. 2019. V. 6. Available at: https://dilemascontemporaneoseducacionpolitica-yvalores.com

10. Olenich T.S., Maslova Yu.V., Klimenko T.M., Zakharova V.A., Astakhova A.I., Vodenko K.V. Eco-Legal Education and Religious Values: The Opportunities of Convergence. Ekoloji. 2019. V. 28. No. 107. pp. 5045-5048. 